\title{
Back to the Past: Evolution of Kidnapping and Hostage Taking in the Niger Delta, Nigeria
}

\author{
Isaac Olawale Albert* ${ }^{*}$, Nathaniel Danjibo, Olumayowa Albert \\ Department of Peace, Security and Humanitarian Studies, University of Ibadan, Ibadan, Nigeria \\ Email: ^ioalbert2004@yahoo.com, danjib@yahoo.com, mayowa4albert@yahoo.com
}

How to cite this paper: Albert, I. O., Danjibo, N., \& Albert, O. (2020). Back to the Past: Evolution of Kidnapping and Hostage Taking in the Niger Delta, Nigeria. Beijing Law Review, 11, 211-226. https://doi.org/10.4236/blr.2020.111015

Received: January 19, 2020

Accepted: March 15, 2020

Published: March 18, 2020

Copyright (อ 2020 by author(s) and Scientific Research Publishing Inc. This work is licensed under the Creative Commons Attribution International License (CC BY 4.0).

http://creativecommons.org/licenses/by/4.0/ (c) (i) Open Access

\begin{abstract}
Kidnapping is now a disturbing security problem in Nigeria. Using ideas pieced together from newspapers, magazines and interviews this paper traces the origin of the problem to the crisis in the oil-rich Niger Delta region in the 1990s. The paper discusses how the Niger Delta militants used it as a pressure tactic for getting the government to address the grievances of oil pollution in their communities. The victims, at the initial stage, were expatriate oil workers. They were taken and political demands made for their release. In the second stage of the problem's evolution, the militants collected ransoms for releasing their captives and the money used it to finance their insurgency against the Nigerian state. The third stage of the evolution was when it was hijacked by some criminal elements that turned it to a form of extortionate terrorism now difficult to manage. At this stage, the oil workers, members of their families, rich community members and politicians were kidnapped and ransoms taken before releasing them. The problem soon extended to the other parts of the country from the Niger Delta because of the poor way this form of violent extremism was managed by the Nigerian state. Not even the amnesty granted the Niger Delta militants in 2009 and in several other parts of Nigeria (where kidnapping now takes place) has been good enough to stop what now appears to be career criminality.
\end{abstract}

\section{Keywords}

Kidnapping, Niger Delta, Niger Delta Militants, Oil, Nigeria

\section{Introduction}

Kidnapping has today emerged as the number security problem in Nigeria. The Boko Haram terrorists in the northeastern parts of the country engage in it for three major reasons. They execute some of the captives for demonstrating how 
brutal they are and could be. The summary executions are usually recorded on video and posted in social media for everybody. They also engage in kidnapping for making political demands: most especially the release of some of their members in detention. The third reason for engaging in the kidnapping is to fund their activities. In this last case, they take some people and ask the government or the family members to pay some ransoms for their release (Ngwama, 2014; Ibrahim, 2017; Albert, 2017a). The bandits in the northwestern part of the country also engage in extortionate kidnapping. They take community members and ask their relations to pay for their release. The other parts of Nigeria are not spared from this problem. As the problem escalates across the country, the question is usually asked: "How did we get here". The usual answer is that it all started from the Niger Delta territory. This paper provides the history of the problem in the oil-rich Niger Delta area.

The point is well made in existing works (Bassey \& Oshita, 2007; Akinwale \& Osabuohien, 2009; Ogbogbo \& Muoajama, 2007/2008; Sunday, 2004; Anele \& Ooro, 2012; Amaraegbu, 2011) that the oil-rich Niger Delta region of Nigeria has been the hotbed of mass-based violence in Nigeria since the 1990s. This has to do with the persistent allegation of the people that oil exploration and exploitation activities degrade their physical environment thus putting pressure on their livelihood. The people also blame the government of Nigeria for allocating too little from the oil earnings to the development of their region. The youth in the region engage in different forms of violence to express their anger against the government and oil companies on these issues. Oil companies face more problems as they are the only institutions that the militant youths could see on the ground. Their oil flow stations are attacked; pipelines are blown up; oil vessels are seized on the high sea and the militants engage in kidnapping and hostage taking of expatriate oil workers and their family members. This paper, which deals with the phenomenon of kidnapping and hostage taking establishes the difference between the two types of terrorism; it discusses how kidnapping all started as a political tactic and later turned into an act of career criminality in the region. It also discusses the extent to which kidnapping and hostage taking forced some expatriate oil workers out of Nigeria and evaluates the response of the Nigerian state to the problem. The issues raised in the paper cover the period 1999 to 2009.

Before 1999, kidnapping was hardly known in Nigeria but as a result of the transition from military to civil rule in 1999 , tension started to heighten between the people of the oil-rich Niger Delta and the oil companies in their communities over issues relating to environmental degradation and lack of basic social amenities in these communities. From 2007 to 2008, some criminal elements within the Niger Delta started to engage in kidnapping purely for criminal reasons. It was from here that the problem went to the other parts of Nigeria with the Southeastern part of the country being the most affected now.

Niger Delta militants, most especially those in the Niger Delta People's Vo- 
lunteers Force (NDPVF) and the Movement for the Emancipation of Niger Delta (MEND), reacted in various violent ways against the oil-related crises in their region until the 2009 amnesty programme that "decommissioned" several of them (Albert 2018; Albert et al., 2019). They blew up oil pipelines; kidnapped oil workers, and sometimes killed them. They supported illegal oil bunkerers and scoopers, and also engaged in arms trafficking. The criminals were supported by illegal oil syndicates whose members included "top police, military and security chiefs, very highly placed politicians, and some first-class traditional rulers" ( Tell April 19, 2004:19). The oil stolen from the Niger Delta on a daily basis, according to Shell sources in 2004 was put at between 60,000 to 90,000 barrels per day. The Nigerian Navy believed that the figure could be as high as 150,000 barrels per day. This is a serious national security issue given the fact that Nigeria gets about $90 \%$ of her export earnings from oil. Commenting on this unfortunate situation, Tell Magazine (Tell April 19, 2004:19) reported that the militant youths "themselves control the bunkering routes and the creeks. Because of their mastery of the areas, the rest of the mafia (in the oil theft business) must necessarily defer to them if they must pass freely. Security sources say that control of the bunkering routes rather than politics is responsible for much of the unrest in the Niger Delta".

The two most consistent strategies used by the militants were bombing of oil flow stations and kidnapping or hostage taking of oil workers. The focus of the present paper is on kidnapping and hostage taking. What is the difference between the two? "Kidnapping" as used in this study refers to situations of abduction "where the location of the subject and victim are typically unknown" while "hostage-taking" refers to situations "where the subject and the victim are contained within a police perimeter" (Fuselier n.d.). Both kidnapping and hostage-taking are included among the forbidden military tactics identified as terrorism in different parts of the world. They are basically violence against civilians and therefore a major human security question.

Kidnapping could be organized for political or economic reasons. Our understanding of the distinction between the two is enriched by the position of Lipsedge when he tried to differentiate between the expressive and instrumental dimensions of the phenomena. The "expressive" motive, according to him, refers to the use of kidnapping or hostage taking as a supplement tactic for ventilating and/or publicizing a grievance or expressing frustration. The "instrumental" motive, on the other hand, has to do with the use of the act to obtain a particular benefit such as ransom. He argued that in many cases, the two motives are interlinked. For example, a terrorist group could take hostage both to express a grievance while at the same time using the opportunity to generate the needed financial resources for continuing their violent extremism (Lipsedge 2004: pp. 24-26). Fitzgerald (1978) came to similar conclusion: that it is common for terrorist organizations to abduct people for attaining both political and fund raising objectives. To this end, a group engaged in extortionate terrorism could confuse 
issues by claiming to be engaged in a revolutionary struggle. The Niger Delta region of Nigeria faced this problem for a very long time.

Kidnapping, whether done for political or economic reasons, constitutes both state and human security questions. As a state security problem, it tarnishes the image of a country and makes it unattractive to foreign investors and tourists. As a human security problem, it traumatizes the larger population as their physical safety, social and economic wellbeing are endangered. Hence, it is the responsibility of every state to ensure that the problem is not allowed to fester for too long. It is unfortunate that this problem has continued for too long in Nigeria. The scale has also been expanding. This makes kidnapping and hostage taking a problem of significant national importance in the country today.

\section{Cases of Kidnapping and Hostage Taking}

The use of kidnapping and hostage taking became prevalent in Nigeria starting from 1999 when the military handed over power to civilians. The Niger Delta militants saw the political transition as an opportunity for them to renew their pressure of getting the Nigerian state to listen to their grievances. To a large extent the strategy worked on the account of the fact that the Nigerian state depends largely on the oil economy. As the militants attacked the oil workers and facilities in their communities, the federal government of Nigeria granted the people of the Niger Delta several concessions in quick succession. On 5 June 2000, the government established the Niger Delta Development Commission (NDDC) with the sole mandate of developing the oil-rich Niger Delta region of Nigeria. The Ministry of Niger Delta was also established on 10 September 2008 to promote accelerated development of the region. The federal allocation to the Niger Delta region from the oil revenue was also increased by the federal government from 11 to 13 percent. In addition to all these, the oil companies operating in the Niger Delta threw more resources into the financing of their corporate social responsibilities. However, none of these interventions had any remarkable impact on the reduction of violence in the Niger Delta region. Kidnapping and hostage taking continued unabated in the region.

Oil workers were the main target of the Niger Delta phase of the problem from 2002 to 2008 (Danjibo and Nwiline 2009). Victims were taken at oil flow stations and on their ways to their project sites. The others were construction workers on contracts with oil companies, state and federal government officials as well as a crew of oil vessels along the Gulf of Guinea. Also included in the list were children of prominent individuals: politicians, contractors and oil workers. However, the ransoms charged at this moment were often modest and not difficult for the victims to pay. Unlike the situations in Iraq and Afghanistan (Alexander \& Klein, 2009: p. 17), the kidnappers and hostage takers in the Niger Delta hardly kill their victims. Victims were released immediately after agreeing on the amount to be paid.

The first major case of kidnapping of foreign oil workers in the Niger Delta 
took place in April 2002 when some youths from Ekeremoh Local Government Area of Bayelsa State abducted ten workers of the Shell Petroleum Development Company (SPDC). The militants asked for and were given a ransom of N3.1 million before releasing the expatriate oil workers to the former Governor of the state - Diepreye Alamieyeseigha. The next one took place almost a year later June 29, 2003. But since then, hostage taking and kidnapping had become a regular occurrence (O'Neil and Ombe 2007) in the region. At this initial stage, the militants were believed to be engaged in political kidnapping. However, it was difficult to clearly understand what the issues were beyond asking the oil companies to pay ransoms for the release of their staff. The goal at this level was more for raising money to continue the insurgency in the Niger Delta. However, the situation changed from 2005 to 2007. During this period, the militants-most especially members of the Martyr Brigade and the Movement for the Emancipation of the Niger Delta (MEND) - started to use kidnapping and hostage taking to establish bargaining position and to elicit publicity for getting Asari Dokubo, the leader of Niger Delta Peoples Volunteer Force (NDPVF) and Diepreye Alamieyeseigha, the former Governor of Bayelsa out of jail. While Dokubo was detained for his leadership roles in the Niger Delta militancy, Alamieyeseigha was detained after he jumped bail in a London Court in 2005 on charges of money laundering; only to return home to be impeached from office in 2006 on charges of official corruption. ${ }^{1}$ It is not unlikely that the hostage crisis at this moment contributed to the eventual release of the two prominent Niger Deltans by the Federal Government in 2007.

Rather than reduce, kidnapping and hostage taking increased after the release of Dokubo and Alamieyeseigha. The incarceration of the two Niger Delta leaders seemed to have contributed to the process. The point was earlier made that Alamieyeseisgha, who was celebrated by the Niger Delta militants as "Governor General of Niger Delta", helped to secure the release of those abducted in the past. His detention probably denied the militants the opportunity of any other Niger Delta leader that could pressure them to stop the criminal act. What more? His detention and the detention of Dokubo provided the militants the political reasons to abduct more people and now for as long as they wanted. Things got so bad that in 2007 Yun (2007: p. 141) listed Nigeria alongside Iraq, Afghanistan, Russia, Colombia, India, the Philippines, and Nepal as the "hotspots" of international terrorism in the world. What became clearly evident at this stage is that there were two categories of hostage takers in the Niger Delta region: those that were truly involved in the political struggle to emancipate the people of the region and those engaged in career criminality. The former, which consisted of MEND, NDPVF and a few other groups, were opposed to spate of kidnappings

\footnotetext{
${ }^{1}$ Leaders of the different social movements in the region had same belief. For example, Comrade Joseph Evah, Facilitator pf the Ijaw Monitoring Group, was reported to have said on one occasion: "If Dokubo-Asari is not released, hostage taking will not stop. Dokubo-Asari is a hostage of the Federal Government and that is why the militants are taking people hostage. If he is released today, that will be the end of hostage taking", The Nation on Sunday, July 13, 2007 p. 14.
} 
and hostage taking that took place after the release of Dokubo (Olatunji, 2007: p. 15) as it was said to undermine the integrity of the Niger Delta struggle. Dokubo himself could not but openly condemn what he saw when he came out of detention. He said:

We must condemn it in all ramifications. If we want people to do justice to us, we must do justice to others. The people we are taking hostage and keeping against their will, is it justice? They are businessmen. They called them to come and do business anywhere. But they too have their blames. We say 'leave our land' but they are trespassing on our land, we say go they say the Nigerian military is there to protect them. They should leave our land, they should go home peacefully. When we have resolved (sic) at the Sovereign National Conference, they should come back (Dokubo, 2007: p. 10).

Ending kidnapping and hostage taking in the Niger Delta at this time required more than engaging the militant youths in the region. There were other stakeholders in the "business" that must be considered. Some of these people included those who acted as negotiators between the kidnappers and the government or oil companies. They added to the problems as they earned their living from the criminal acts. Chief Edwin Clark, an Ijaw leader, gave insight to this problem while addressing newsmen immediately Dokubo was released from detention. He too took the media through the history of kidnapping and hostage taking in the Niger Delta. He observed that at the initial stage, the militant took hostages to draw the attention of the Federal government to the bombardment of some Ijaw villages by the military who claimed to be searching for illegal oil bunkerers. The system later became criminalized as some of the boys started kidnapping oil workers for ransom. He cited the case of a Chief Security to a former governor of Rivers who made big money from bargaining with kidnappers. He cited a specific instance in which some boys got N20 million to effect the release of some hostages. The boys disappeared with the money as soon as it was given to them. Another set of boys got N30 million to release the same set of hostages. The work was done but the boys discovered later that the government had actually released N300 million for the job. Someone along the line (state officials) had swindled them. Chief Clark observed that some oil workers were also part of the racket (Amaize, 2007b: p. 11). They colluded with hostage takers and in the process made their own profits. In other words, it was not in the interests of any of these stakeholders to see kidnapping ended in the Niger Delta.

The fusion of greed and grievance in the hostage taking phenomenon was addressed by Dokubo in one of the interviews he granted. He observed that shortly after he was released from detention, some boys (most likely members of his NDPVF) came to him to say they had taken some oil workers (from Schlumberger). Rather than participate in the criminality, he helped to facilitate the release of the hostages. Based on his interaction with the kidnappers, Dokubo observed in 2007 that it would prove very difficult for the hostage taking business 
in the Niger Delta to end. He noted in broken English "it has gone beyond what an individual can change overnight because of the money don sweet for people mouth. So, anytime dem see oyinbo, dem go catch am and if they see you sef dem fit catch you. Because they know say money fit come (Dokubo, 2007: p. 12).

Whereas those kidnapped or taken hostage for the release of Dokubo and Alamieyeseigha were strictly non-Nigerian oil workers, the victims of their successors included Nigerians and even people of the Niger Delta that the militants claimed to be fighting for. Those taken hostage or kidnapped included children, grandparents, politicians, military officers, pastors, etc. At this level, the 2007 position of Yun (2007: p. 161) on the victims of the problems in Niger Delta was no longer valid that the "targets of hostage-taking and kidnapping (in Nigeria) are exclusively employees of multinational oil corporations or workers of subcontractors affiliated with those oil companies". Everybody with the right hostage value was targeted. Many fled the Niger Delta region.

As the government launched different forms of military attacks on the communities in which these kidnappers were suspected to be domiciled, MEND which was equally antagonized by the government as a militant organization tried to sanitize the Niger Delta region by deterring the criminals from continuing their acts which gave the struggle a bad name. MEND tracked some of the hostage takers down and freed the hostages. One of such cases was reported in The Nation newspaper (7 November 2008:8). A Lebanese, Mr. Melad Nasari, an employee of Homan Engineering Company Port Harcourt was abducted in October 2008. MEND promised to help in securing his release and succeeded in doing this on 5 November 2008 when they stormed the hide-out of the kidnappers. In the process, MEND came across a few other abductees one of whom was one Mr. Patrick Akorodu, a bank manager in Omoku Branch in Rivers State, securing the release of the hostages did not take place without the exchange of gunshots between the militants. Lives were lost but MEND saw it all as part of the sacrifice it had to make for sanitizing the Niger Delta communities of kidnapping and hostage taking.

On some occasions, MEND promised to halt kidnapping in the Niger Delta if the former head of state, Chief Olusegun Obasanjo who ruled Nigeria from 1999 to 2007, could be sent out of power. President Obasanjo left office on May 29, 2007. MEND celebrated this by releasing the six political hostages in their custody. The exercise was packaged as a "farewell gift" to Obasanjo. But it was not for free; the hostages were formally handed over to Governor Timbre Sylva of Bayelsa State after the payment of an undisclosed ransom (Agbo, 2007: p. 26).

However, many other militant groups simply continued the hostage taking "business" after the exit of Obasanjo. Barely a month after the departure of the former president, no less than seven major cases of hostage taking and kidnapping took place in Akwa Ibom, Bayelsa, Delta and Rivers States with more of the cases taking place in Rivers. The two most advertised of the cases was the June 1, 2007 kidnapping of some Indian workers of Indorama, the new owners of the 
Eleme Petrochemical Company Limited sold by the Burea of Public Enterprises. This was the second time that the company would be attacked by hostage takers. During the first attack (three weeks before the second), the militants that called themselves the Movement of Niger Delta People took three hostages. They asked for a ransom of N150 million: N50 million per hostage. The Indian company paid a "paltry" N40 million and the militant struck the second time and took the Managing Director of the company. They described the N40 million earlier paid to them as the feeding allowance for the hostages they initially took and threatened not to release any of the hostages until the N150 million they initially asked for was paid in full (Agbo, 2007: p. 36). The next day, another militant group struck at the Aluminum Smelting Company of Nigeria Limited at Ikot Abasi, Akwa Ibom State. They kidnapped five Russian workers (Agbo, 2007: p. 36).

Another false hope that the hostage taking saga was reduced came on July 1, 2007 when Ateke Tom, the leader of the Niger Delta Vigilante (NDV) and the heads of a few other rival militant groups ${ }^{2}$ who had engaged each other in fierce battle for supremacy in the Okrika axis and some other parts of Rivers State signed a peace deal brokered by the Kiriike-Be-Se Peace and Development Project and the Wakirike United Peace Guild in which they renounced violence and pledge support for the war against hostage taking and kidnapping. The event, which was attended by the Chairman of the Okrika Local Government Council and the Amanayanabo of Koniyu, Captain Nemi Tamuno Iyalla Oputieya $\mathrm{X}$. The process included the militants taking the Christian and traditional oaths, pledging to assist in the rehabilitation of displaced people and becoming fully integrated into the communities. This political settlement could not stop economic kidnapping in the region.

Kidnapping and hostage taking continued unabated in the area and other parts of the Niger Delta after this exercise suggesting that the perpetrators were no longer deterred by any religious oath taking: whether Christian or traditional. The most targeted were bankers, their relatives and customers departing banking premises with huge sums of money. The police were helpless about the situation. Following the kidnapping of a bank manager's wife in November 2008 in Abia State, all the banks in the state shut down operation as a way of expressing the displeasure of the bankers against kidnapping and hostage taking. Commenting on the situation, the bankers who spoke through one of their officers on condition of anonymity said: "The number of kidnap cases have (sic) kept increasing in recent times, and now one of our members had his wife kidnapped, this means that nobody is safe in the state again ... the police cannot do anything to stop the increasing number of kidnap cases, and so the governor should look

\footnotetext{
${ }^{2}$ Namely the Icelanders also commanded by Tom Ateke, Niger Delta Solidarity Front led by Abiye Abaku, Klans Men led by Petetoru Iyaye, Green Landers led by Theophilus Fubara, Black Axe led by Glory Iyango, and the Bushboys/Peace makers led by Sunny Opuambe,a and the Outlaws led by Sampson Adoki. See Kelvin Ebiri, "Ateke Tom, Militants renounce violence”, The Guardian, July 15, 2007 p.1; Bolaji Ogundele, "Ateke Tom, six other cult groups agree to end armed rivalry", Sunday Tribune, July 15, 2007 p.4.
} 
towards other means to curb the menace" (Eke, 2008: p. 8). Gradually, the problem extended to the other parts of Nigeria.

\section{Boomerang Effects}

The hostage taking incidences seemed to have completely diluted the revolutionary message and stance of the Niger Delta militants; it turned them to self-seeking elements in the public glare. Hence, members of the international community and Nigerians alike started to see the boys involved in kidnapping as nothing but a bunch of criminals. The situation became more worrying when the kidnappers started to abduct children. Commenting on this, a newspaper columnist said: “... What we are now dealing with is depravity of the highest order and a descent to the lower depths of humanity. Kidnapping a child is so easy and cowardly. A child is defenceless even when accompanied on the way to school by a driver or nanny. There is no prior preparation for an attack or any form of protection" (Abati, 2007: p. 54).

Kidnapping and hostage taking boomeranged on the Niger Delta communities as well. Several companies had to move their offices from Port Harcourt to Lagos. All Governors of the Niger Delta states were challenged by the federal government to arrest the situation. Immediately after he was sworn in as the Governor of Bayelsa state on May 29, 2007, Governor Timipre Sylva pledged to stop hostage taking in his state. He put a number of measures in place to achieve this goal but the problem escalated rather. Worried by this development, the Governor had to formally task the umbrella body of the Ijaw-the Ijaw National Congress - to help him engage the Niger Delta militants in constructive dialogue with a view to checking the incidence of hostage taking. Justifying the need for such an intervention, he argued that the investment climate worsened of the state and the revenue accruable to Bayelsa state had nose dived as a result of both hostage taking and vandalisation of oil facilities in the state. He noted additionally that some federal projects in the state had stopped as a result of the withdrawal of the contractors from site. One of these projects was the dualisation of the East-West road. He offered to host a Pan-Ijaw Congress to discuss the matter if the Ijaw National Congress could convene it (Folaranmi, 2007: p. 53).

As a result of this problem, many expatriate oil and construction workers and even their Nigerian counterparts in some cases, had to abandon their stations and flee to either Lagos or traveled back to their countries. This has a telling effect on Nigeria's image, Nigerian foreign exchange earning capacity and also the international oil market. Commenting on the implications of this a report of the Central Bank of Nigeria stated that the decrease in the earnings from crude oil caused the federal government and other tiers of government to rely on excess crude oil account to make up for the shortfall in their revenues (Amaefule, 2007: p. 64).

The May and June 2007 kidnapping of the staffers of Indorama created a huge crisis in the organization. Close to seventy of its workers left for India imme- 
diately their Managing Director was abducted. So many Indians were so affected simply because of one of the injustices that the people of the Niger Delta claim to be fighting: the takeover of their economy by "outsiders". The Tell Magazine reported that immediately the former Eleme Petrochemical Company Limited was acquired by Indorama, it was flooded by illegal Indian workers contrary to the terms of the agreement of the terms under which it was acquired. The management of the company was said to have instructed some of its Indian employees to go into hiding when Mr. Funso Kupolokun, the Managing Director of Nigeria National Petroleum Corporation (NNPC) visited the company before the hostage crisis (Agbo, 2007: p. 36).

The then Governor of Delta State, Dr. Emmanuel Uduaghan, was as disturbed and frustrated as his Bayelsa counterpart. One of his very first unofficial assignments was to secure the release of four American workers of Global Industries who were taken hostage on May 8, 2007 by a group that called itself "Niger Delta Freedom Fighters" (NDFF). The group which was also known as Egbema one was based in Warri North Local Government Area of Delta State. Following his inauguration on May 29, 2007, the governor set up the Delta Waterways Security Committee which was charged with the responsibility of ending hostage taking and other forms of criminal activities relating to waterways within six weeks. Fifteen days (June 15) after which this committee was set up, some militants struck in Sapele, a town with no history of hostage taking. The two Indian hostages were Murughan Gopal and Anthony Marian of an Ogbara-based rubber plant. A delegation of the Waterways security committee met with the hostage takers on June 26 during which the latter asked for ransom of N50 million for the release the Indians. They later reduced this to N12 million but the committee claimed to lack the power to enter into such an agreement. They had to return to the Governor who claimed that his regime would rather invest in projects that would improve the conditions of Delta state within 100 days than pay such money to hostage takers (Amaize, 2007a: p. 12).

Due to the devastating effect of the hostage taking saga, Shell Petroleum Development Company in June 2007 had to formally meet the governor of Rivers State, Celestine Omehia to help in stemming the rising wave of insecurity in Rivers. The company could not relocate to Lagos as done by many other companies simply because the majority of its operation bases are in the Niger Delta (Ebiri, 2007: p. 25). Yet, hostage taking was negatively impacting on its business. The position of the Federal Airport Authority of Nigeria (FAAN) reconstructing the airport in Port Harcourt was not different from that of the SPDC. They too complained that the completion of the rehabilitation of the airport was slowed down by the activities of the hostage takers as most of the contractors handling the project were foreigners who feared being kidnapped. As Akin Olukunle, the General Manager (Public Relations) of FAAN observed: "35 percent of the work has been completed before the contractors Julius Berger stopped work for security reasons". This resulted in loss of revenue for the airport authority and 
caused great discomfort for members of the public that require the airport for traveling out of Port Harcourt.

\section{Response Analysis}

How did the oil companies and the federal government of Nigeria most affected by this problem handle the situation? Most of the time, the government tried to allay the fears of the oil companies operating in the Niger Delta as well as members of the international community by claiming that the military sent to the region had the capacity to deal with the problem. But the oil companies operating in the region preferred to pay up the ransom negotiated with the kidnappers and hostage takers. They did not believe much in the ability of the government to protect them as some of the military men sent to the Niger Delta region to provide security were themselves kidnapped in some cases.

In reality, the federal government oscillated back and forth from denial of the seriousness of the problem to the use of excessive force in dealing with the situation. Technically speaking, denial is a defence mechanism in which a person that is overwhelmingly implicated in a problem tries to "deny the reality of the unpleasant fact altogether (simple denial), admit the fact but deny its seriousness (minimisation) or admit both the fact and seriousness but deny responsibility (transference). The Nigerian state engages in minimisation most of the time. This is done through the government's consistent claims, each time hostages were taken, that the particular incident is a one-off incidence (Ike-Okoh, 2007: p. 4). In some cases, the magnitude of the problem is played down by blaming the media organisations that reported them. This brought the government and the media on collision paths several times.

In fact, Jeff Koinange the African correspondent of the Cable Network News (CNN) lost his job in 2007 as a result of his reports on hostage taking in the Niger Delta. He was featured in a report in the midst of fire spitting militants and some Filipino taken hostage. The militants were in a ritualistic dance and chanting gibberish while firing machine gun shots into the air to scare their hostages and the reporter. The federal government, through the Minister for Information, Frank Nweke Jr. accused him of misinforming the world about the problem. According to Nweke, the report was stage-managed. Hence, CNN was put under pressure to sack Koinange. But the world knew that the young man simply lost his job for what is best described as "investigative journalism" in an atmosphere of obvious state denial of truth. Responding to the charge by the government that the situation was stage managed, Sola Fasure argued in the Nation Newspaper:

I am appalled that the minister could deny that there was military escalation in the Niger Delta or that CNN stage-managed what was obvious throughout the country. The minister's illogic was stunning. The 24 Filipinos had been kidnapped long before the CNN story. Koinange was brought to face them and even interviewed some of them, which was shown on CNN. 
Could CNN have bribed the masked men who kept 24 people in custody to grant an interview? How much could $\mathrm{CNN}$ have paid those who collect ransom in hundred of millions? ... It is common knowledge in the Niger Delta and indeed throughout Nigeria that the militants are the masters of the creeks. The ease with which they have carried out their operations is second to none. They have access to cash from ransom money and crude oil theft and therefore can afford to buy sophisticated weapons which are not even available to Nigerian law enforcement agents (Fasure, 2007).

Indeed, the government had some military structures on the ground for contending with the problem. The problem, as indicated by Fasure above, is that the militants were not easy to handle by the army. As early as 2003, the government had set up a Joint Task Force (JTF) consisting of the military (Army, Navy and Airforce), the police and State Security Services (SSS) to take full charge of the security of the Niger Delta region in addition to the existing security systems in this part of Nigeria. JTF had two flanks. The first known as "Operation Restore Hope" which was established to take charge of the various cases of terrorism in the city of Port Harcourt in 2003. "Operation Flush Out III" took off in Warri, another trouble spot, in 2004. The two military operations were merged into one in 2009 when acts of terrorism became heightened and wider spread in the Niger Delta shortly before the amnesty programme of the federal government that finally reduced the problem. The main duty of JTF was to prevent and counter militants activities in the creeks. In the process, some members of the taskforce were themselves taken hostage or/and killed.

However, military operations had drawbacks and limitations. A case in point was the management of the invasion of the Shell Petroleum Development Corporation and kidnapped four expatriate oil workers in January 2006. This particular incident was unique because of the sophistication of the kidnapping process. Also, the prevailing political environment in Nigeria at the time of the incident and the volatility of the global oil market during the period drew the attention of the international community to this incident. Within the period of 20 days during which the kidnapping and hostage taking lasted, global oil price soared from 63.95 dollars to 69 dollars per barrel. Diplomatic pressures were exerted on Nigerian government to effect the release of the hostages, who included an American, a Briton, a Bulgarian and a Honduran. The first reaction of Nigerian government was to tag the kidnappers as terrorists, and several options were considered for rescuing the hostages, with military options highly preferable. This particular incident actually gave birth to the military task force, codenamed "Operation Restore Hope". The American government supported the task force with four gunboats to execute the mission (Tell Magazine, 2006: pp. 22-23).

However, when it was clear from intelligence reports that the kidnappers were employing sophisticated methods, weapons and communication equipment to prosecute the hostage taking and they were likely to resist any forceful attempt to rescue the hostages, peaceful negotiation of the release of the hostages was con- 
sidered by the government. In addition, the identity of the particular militia group which kidnapped the expatriates among the numerous gangs operating in the terrain was not initially clear since as many as 50 of the discreet groups were claiming responsibilities for the incident, or claiming to have access to the hostages, and were inviting the government for negotiation. This also probably made planning difficult for any effective military option to rescue the hostages. Also during the incident, several skirmishes took place between armed bandits and security men in the area, during which many security personnel, including soldiers were killed ${ }^{3}$; and so the government was not too encouraged to pursue military option in spite of the diplomatic pressure exerted by the home governments of the hostages. It was therefore reasoned that any misadventure could cause loss of troops and equipment which the military could ill-afford in a confrontation with obviously well trained and well organized Niger delta militia.

The bloodiest counter-insurgency attacks against the militants after the May 29, 2007 transfer of power from Obasanjo to Yar'Adua took place on June 22, 2007 as a result of which twelve of them were killed and five others captured alive. The operation which led to the release of 27 hostages took place at Ogboinbiri flow station owned by Nigerian Agip Oil Company (NAOC) which the militants had been occupying for days. The military operation was launched at the expiration of the 48-hour ultimatum given by the Federal Government to the government of Bayelsa State to produce the 11 soldiers seized by militants at the Agip oil facility for a week. None of the soldiers were however found, whether dead or alive, at the end of the counter-insurgency (Oyadongba, 2007: p. 3). Frustrated by his inability to find any lasting solutions to the problem of violent extremism in the Niger Delta, President Yar'Adua started an amnesty programme for the militants in the region in 2009. Those who laid down their arms were provided life economic support and restored to their communities (Albert, 2019). But this did not completely stop kidnapping in the region. It also did not stop the problem from spreading to the other parts of Nigeria. Kidnapping is now Nigeria's number one security problem. Many criminal groups in the country seek to make as much money from victims as the Niger Delta militants did in their region.

\section{Summary of Findings}

The above story line is straight forward on the origin and escalation of kidnapping in Nigeria. The country would probably not have known kidnapping the way it is if it had handled the Niger Delta crisis more carefully. The degradation of the Niger Delta communities by oil prospecting activities is an obvious problem in the region, even now. The fact also remains that the federal government and the oil companies operating in the region has never shown any serious interest in addressing this problem. Hence, the militant youths in the Niger Delta

${ }^{3}$ These incidents did not have anything to do with the kidnapping being discussed. They were only part of normal skirmishes, which occur constantly in the Niger Delta. They were reported widely in the Nigerian media. 
took advantage of this gap to start using kidnapping and hostage taking as a method for getting the oil companies and federal government to listen to their grievances. It is unfortunate that the oil companies in the region started showing interest in payin the boys off. The ransoms collected made the militants start seeing kidnapping as a lucrative business which is today all over Nigeria. Unfortunately, the law enforcement system in the country is not good enough to address the problem. Those kidnapped now pay for their freedom and this seems to further incentivize the criminal activity.

\section{Conclusion}

A lot is being invested in the management of the problem of kidnapping by the federal government of Nigeria but the efforts do not seem to be good enough at reducing the expansion of the scourge. Boko Haram insurgents in the North East abduct people regularly; the bandits in the North West equally do. So also are several other criminal elements seeking to make money from extortionate terrorism. Some of the suggestions made for preventing and managing the problem is that the country should start the practice of community policing. This suggestion is based on the belief that the perpetrators of the criminal acts live within communities where their identities cannot be permanently hidden. Unfortunately, the present criminal justice system in Nigeria is too centralized. It makes too little provisions for community participation in crime prevention and management. Like many African countries, security problems manifest at the local level in Nigeria but their management must await decisions to be taken by the central government (Albert, 2017b). Until this situation changes and the Nigerian state accede to the international pressure for Nigeria to embrace honest security sector reforms, the present crisis would continue and the likes of kidnappers and hostage takers discussed in this paper would continue to have a free day. But the best approach to solving the problem is to address the increasing problem of poverty in Nigeria. The present regime in Nigeria promises to take 100 million Nigerians out of poverty in the next ten years. This is a loud admittance of the fact that more than 50 percent of Nigerians are in a state of extreme poverty. Such people are bound to turn to different forms of criminal activities for survival most especially when they find it difficult to see what the government is doing to help them out of poverty.

\section{Conflicts of Interest}

The authors declare no conflicts of interest regarding the publication of this paper.

\section{References}

Abati, R. (2007). The Child-Hostage Takers of the Delta (p. 54). The Guardian, 15 July.

Akinwale, A. A., \& Osabuohien, E. (2009). Re-Engineering of NDDC's Master Plan: An Analytical Approach. Journal of Sustainable Development in Africa, 11, 144-152. 
Albert, I. O, Olarinde, Y. T., \& Albert, O. O. (2019). Order outside the Law? Rethinking Amnesty as an ADR Mechanism in Nigeria. Beijing Law Review, 10, 913-925. https://doi.org/10.4236/blr.2019.104049

Albert, I. O. (2017a). Bring Back Our Girls: The Impact and Limits of a Nigerian Hash Tag Activism. In I. O. Albert, S. Omotoso, \& A. Akeredolu (Eds.), Gender Based Violence in Contemporary Nigeria. Ibadan: Institute for Peace and Strategic Studies, University of Ibadan.

Albert, I. O. (2017b). Security Regimens in Africa. CODESRIA Policy Briefs, Number 3 June, Dakar: Council for the Development of Social Science Research in Africa (CODESRIA).

Albert, I. O. (2019). Hazy Agenda, Multiple Interests: Stakeholders Engagement with the First Phase of the Niger Delta Amnesty Deal in Nigeria. Beijing Law Review, 10, 656-670. https://doi.org/10.4236/blr.2019.104037

Alexander, D. A., \& Klein, S. (2009). Kidnapping and Hostage-Taking: A Review of Effects, Coping and Resilience. Journal of the Royal Society of Medicine, 102, 16-21. https://doi.org/10.1258/jrsm.2008.080347

Amaize, E. (2007a). Uduaghan's Men in a Battle of Wits with Militants (p. 12). Saturday Vanguard, 23 June.

Amaize, E. (2007b). With Dokubo's Release, the Path to Peace Is Clear...but Say N/Delta Leaders (p. 11). Saturday Vanguard, 23 June.

Amaraegbu, D. (2011). Violence, Terrorism and Security Threat in Nigeria's Niger Delta: An Old Problem Taking a New Dimension. African Journal of Political Science and International Relations, 5, 208-271.

Anele, K. A., \& Omoro, J. (2012). Mobilizing the Militants in the Niger Delta for National Development: Prospects and Challenges. Journal of International Diversity, 2012, 107-122.

Bassey, C. O., \& Oshita, O. O. (Eds.) (2007). The Nexus of Conflict and Development Crisis in Africa. Conflict Resolution, Identity Crisis and Development (p. xv). Lagos: Malthouse Press.

Dokubo, A. (2007). I Was Treated Like an Animal; Many Went Mad Where I Was Kept (p. 10). Saturday Vanguard, 23 June.

Ebiri, K. (2007). Shell Appeals to Rivers Govt over Growing Insecurity (p. 25). Business Guardian, 26 June.

Eke, U. (2008). Bank Shut in Aba over Abductions (p. 8). The Nation, 7 November 2008.

Fitzgerald, B. D. (1978). The Analytical Foundations of Extortinate Terrorism. Terrorism, 1, 347-362. https://doi.org/10.1080/10576107808435419

Folaranmi, F. (2007). Sylva Enlists Group to stop hostage taking...Says revenue to Bayelsa Has Reduced (p. 53). Sunday Sun, 24 June.

Ibrahim, B. (2017). An Analysis of the Causes and Consequences of Kidnapping in Nigeria. African Research Review, 11, 134-143. https://doi.org/10.4314/afrrev.v11i4.11

Ike-Okoh, C. (2007). Niger Delta kidnappings: Perception, Denial and Reality for Investment (p. 4). Business Day, 11 July.

Ngwama, J. C. (2014). Kidnapping in Nigeria: An Emerging Social Crime and the Implications for the Labour Market. International Journal of Humanities and Social Sciences, 4, 133-145.

Ogbogbo, C. B. N., \& Muojama, O. (2007/2008). The Global Economy and the Niger Delta Crises. Journal of the Historical Society of Nigeria, 17, 169-190. 
Olatunji, S. (2007). Asari-Dokubo Carpets FG over Niger Delta Crisis. Sunday Punch, 8July.

Sunday, O. A. (2014) The Niger Delta Crisis and the Roles of Governmental Agencies in Nigeria. African Identities, 12, 180-195. https://doi.org/10.1080/14725843.2014.885779

Yun, M. (2007). Implications of Global Terrorist Hostage-Taking and Kidnapping. The Korean Journal of Defense Analysis, 19, 135-165.

https://doi.org/10.1080/10163270709464138

Fasure, S. (2007). Between Nweke and CNN. The Nation, 17 February.

Oyadongba, S. (2007). Soldiers Reclaim Agip’s Facility, Kill 12 Militants, Free 27 (p. 3). Saturday Vanguard, 23 June.

Amaefule, E. (2007). Oil Revenue Drops to N1.02tn (p. 64). The Punch, 9 July.

Agbo, A. (2007). Mixed Grill from Militants (p. 36). Tell, 18 June. 